\title{
Employee Organizational Commitment Towards Quality Outcomes: A Study in Manufacturing Organization of Nepal
}

\author{
Bhupindra Jung Basnet, MPhil \\ Lecturer, Nepal Commerce Campus, T.U.
}

\begin{abstract}
The purpose of this paper is to examine the impact of total quality management practices on employees' organizational commitment in Nepalese manufacturing industry. Structural questionnaire are used. Data was analyzed by employing correlation and sample regression analysis. The result of this study revealed that training and education, teamwork, and organizational culture are positively associated with employees' organizational commitment.
\end{abstract}

Keywords- Total quality management practices, Employees' organizational commitment, Nepalese manufacturing industry

\section{Introduction}

TQM can be defined as the application of quality principles for the integration of all functions and processes within the firm (Ross, 1993). TQM uses techniques that improve product quality and processes, helping a firm improve its competitive performance (Grant, Shani,and Krishnan (1994). Flynn, Schroeder and Sakakibara (1994) defined that TQM is an integrated approach to attaining and sustaining high quality output, focusing on the maintenance and continuous improvement of processes and defect prevention at all levels and in all functions of the firm, in order to meet or exceed customer expectations. TQM is an organization-wise approach to continuously improve the quality of the organization, processes, products and services (Thapa, 2067).

Boynton and Zmud (1984) clarified TQM practices as those few things that must go well to ensure success. These definitions emphasized gaining a competitive edge and are applicable to all the sectors. This focused on TQM in practice rather than TQM in theory or TQM as organizational change. Hoogervorst, Koopman and Van der Filer (2005) argued that TQM approach requires focus on employee behavior, attention to organizational culture, management practices, and organizational structure and systems. TQM has a people-oriented approach and incorporates many aspects of organizational behavior (Luthans, 1995). Guimaraes (1996) identified several indicators for work- related attitudes. These included task characteristics, job involvement, job satisfaction, career satisfaction, and organizational commitment. The employer introducing TQM seeks to gain employee commitment and co-operation rather than just compliance (Dawson, 1994), and this requires a culture change which includes the greater involvement of employees in the decision making process (Hill, 1991). In theory, TQM is empowering employees to be more involved in their jobs and to participate in TQM decision- making activities. TQM practices produce greater organizational commitment among employees (KariaandAsaari, 2006). TQM practices impact on employees' organizational commitment (Guimaraes, 1996; Ooi, Arumugam and Haw, 2005; KariaandAsaari, 2006). In Nepalese context, TQM practices and employees' organizational commitment have nominal literatures. Thus, this study adds new literature in the field of TQM practices and employees' 
organizational commitment in Nepalese manufacturing industry.

\section{Literature Review}

TQM focuses not only on the quality of product, but also on the quality of employees. Most successful TQM implementations depend heavily on changes in employees' attitudes and activities. In theory, TQM processes produce positive effects on employees by improving their satisfaction and commitment and by enhancing their organizational effectiveness (KariaandAsaari, 2006). Luthans (1995) summarized TQM as being a participative system that empowers all employees to take responsibility for improving quality within the organization. TQM practices identified top management, education and training, employee participation, customer focus, organizational culture, and teamwork (Ooi, Arumugamand Haw, 2005). TQM practices recognized customer focus, training and education, empowerment and teamwork, and continuous improvement and problem prevention (Karia and Asaari, 2006). Guimaraes (1996) identified that work-related attitudes are task characteristics, job involvement, job satisfaction, career satisfaction, and organizational commitment. Organizational commitment is the affective commitment that represents an employee's strong desire to remain a member of a particular organization when the opportunity to change jobs exists (Agarwal and Ramaswami, 1993). Affective commitment refers to the identification with involvement in, and emotional attachment to the organization (Allen and Meyer, 1996).TQM practices influence on employees' organizational commitment (Ooi et al., 2005; KariaandAsaari, 2006; Batista, et al., 2013). Training focused on broadening employees' knowledge and skills can represent opportunities for individual growth (Hunt (1992). Training and education plays a critical role in maintaining high quality level which can be achieved through the best use of talent and activities available within the organization (TalibandRahman, 2010). Training and education was significantly positive related to employees' organizational commitment (Ooi et al., 2005; Karia and Asaari, 2006) but training and education did not show any favorable contribution to the organizational commitment (Batista, et al., 2013). Teamwork means working together and typically involves groups of interdependent employees who work cooperatively to achieve a common goal (Parker and Wall, 1998).Teamworkis a work arrangement that arguably has the capacity to enable cooperation and effective individual involvement and it represents a way of working (Gallear and Ghobadian, 2004). Teamwork had a significant and positive correlation with employees' organizational commitment (Ooi et al., 2005;Karia and Asaari, 2006; Batista, et al., 2013). Organizational culture is to be an important tool for the organizations to reside in the ideas, values, norms, rituals and beliefs in order to sustain organizations as socially constructed realities (Morgan, 1986). Organizational culture refers to a system of shared meaning held by members that distinguishes the organization from other organizations (Robbins, Judge, and Sanghi, 2010). Organizational culture was significantly positive associated with employees' organizational commitment (Ooi, et al., 2005).

In Nepal, Thapa (2011) highlighted the needs of TQM to improve overall quality of education in Nepal. Thapa (2015) identified that management commitment, customer focus, continuous improvement, training and developments, and feedback and effective communication had positive relation with organizational performance in Nepalese tourism industry. In the context of Nepal, there is limited literature of TQM practices effect on employees' organizational commitment. Thus, the key issue of this study is whether TQM practices impact employees' organizational commitment or not in Nepalese manufacturing industry?

\section{Research Hypotheses}

Karia and Asaari (2006) argued that the TQM practices, particularly training and education, teamwork, positively influence the employees' organizational commitment. According to Ooi, et al., (2005), Soft TQM practices, specifically, education and training, teamwork, and organizational culture, positively influences the employees' organizational commitment. Thus, based on the authors previously mentioned, the research hypothesis is formulated. 


\section{Conceptual Framework}

The link between TQM practices and employees' organizational commitment are shown in Figure 1. In this conceptual framework, independent variables of TQM practices are training and education, teamwork, and organizational culture (Ooi et al., 2005; Karia and Asaari, 2006) and dependent variable is organizational commitment (Guimaraes, 1996).

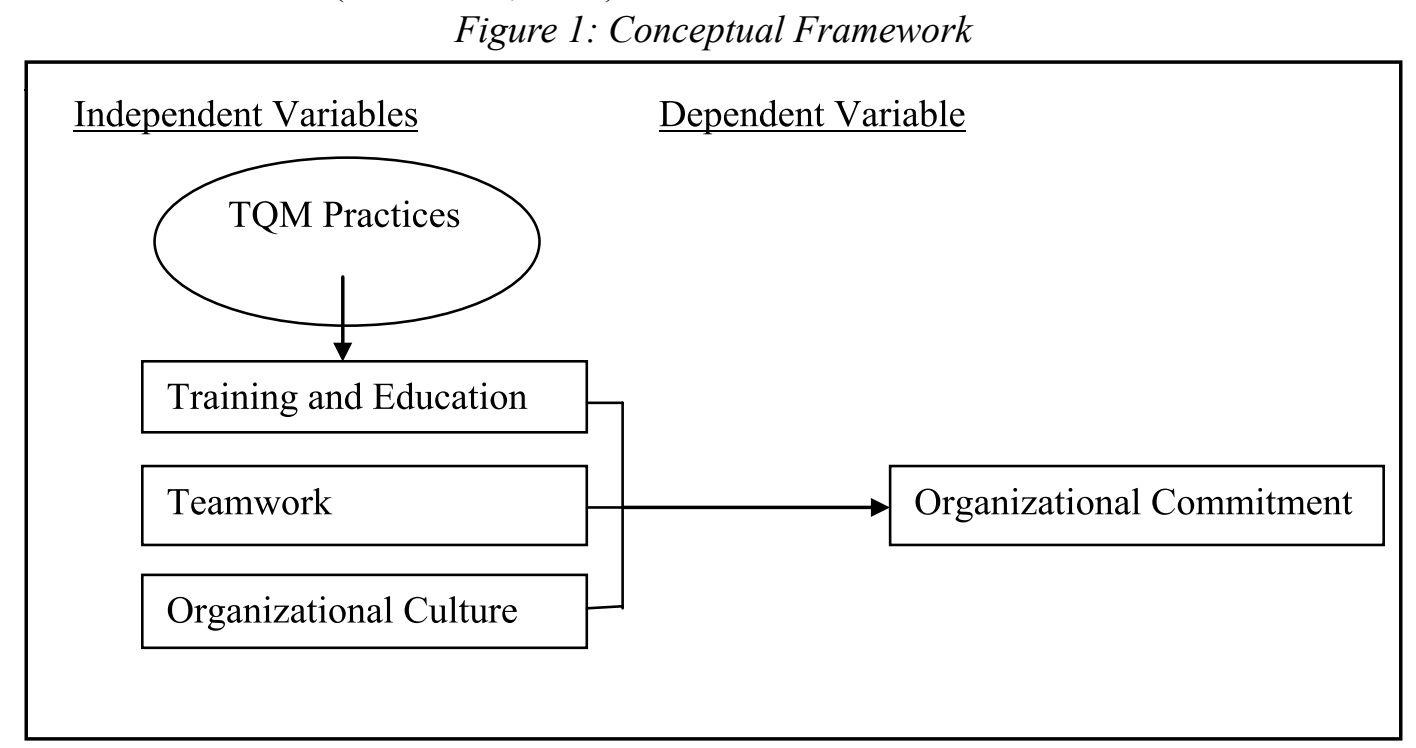

\section{Methodology}

\section{Research design}

Descriptive research design has been used to describe nature of variables so as to develop a better understanding of the employees' organizational commitment, based on TQM practices. Correlational research has been used to determine the relationship between dependent variable (employees' organizational commitment) and independent variable (TQM practices). Causal- comparative research has been used to demonstrate the variation in the dependent variable that can be explained by the independent variable. All employees of manufacturing industries are considered as population of the study. All managers of ten manufacturing industries are sample. Convenience sampling technique is used to select the industries and respondents and their offices of selected industries are in Kathamandu district. Thus, ten manufacturing industries are selected for conducting the study. Primary data have been used. Out of 150 questionnaires are distributed to all managers in these industries, 105 questionnaires are returned however, only 100 questionnaires are usable.

\section{Instrumentation}

Training and education are measured by a five-item scale and ranges from (1) "strongly disagree" to (5) "strongly agree" developed by Zhang (1999). Teamwork is measured by using four-point Likert scale developed by Flynn et al. (1994) and Lau and Idris (2001). In this study, responses are on five- point Likert scale and ranges from (1) "strongly disagree" to (5) "strongly agree". Organizational culture is measured by a four-point Likert scale adapted from Lau and Idris (2001). In this study, responses are on five- point Likert scale and ranges from (1) "strongly disagree" to (5) "strongly agree. Employees' organizational commitment is measured by Mowday et al. (1979) from a 7-point scale. In this study, responses are on fivepoint Likert scale and ranges from (1) "strongly disagree" to (5) "strongly agree. 


\section{Techniques of Analysis}

Frequency distribution has been applied to show the respondent's profile. Mean and standard deviation has been used for descriptive analysis. Correlation analysis has been utilized to identify the relationship between employees' organizational commitment and TQM practices variables. Simple regression analysis has been operated to show the variance in the employees' organizational commitment (dependent variable) that can be explained by the TQM practice (independent variable). The following regression models have been utilized.

The regression equations of dependent variable of $E_{O C}$ with independent variables of TQMP, CF, TE, $\mathrm{T}$, and $\mathrm{OC}$ have been used.

$$
\begin{gathered}
E_{O C}=\alpha+\beta T Q M P+u \ldots \ldots \ldots \ldots \ldots \ldots \ldots \ldots i \ldots \ldots \ldots \\
E_{O C}=\alpha+\beta T E+u \ldots \ldots \ldots \ldots \ldots \ldots i_{1} \\
E_{O C}=\alpha+\beta T+u \ldots \ldots \ldots \ldots \ldots \ldots i_{2} \\
E_{O C}=\alpha+\beta O C+u \ldots \ldots \ldots \ldots \ldots \ldots i_{3}
\end{gathered}
$$

Where,

$E_{O C}=$ Employees' organizational commitment, $T Q M P=$ Total quality management practices, $T E=$ Training and Education, $T=$ Teamwork, $O C=$ Organizational culture, $\alpha=$ Alpha (constant), $\beta=$ Beta (change), $u=$ Error term.

\section{Data Analysis}

\section{Respondent's Profiles}

Table 1

The respondent's profile (personal and demographic information) is presented in table 1.

\begin{tabular}{llcc}
\hline & & Respondents' Profile & \\
\hline \multirow{2}{*}{ Gender } & & Frequency & Percentage \\
& Male & 82 & 82 \\
Marital statues & Female & 18 & 18 \\
& Single & & \\
& Married & 31 & 31 \\
Age group (years) & & 69 & 69 \\
& Less than 25 & & 30 \\
& $25-34$ & 30 & 39 \\
& $35-45$ & 39 & 31 \\
\hline Educational level & & 31 & 30 \\
& Diploma degree & & 65 \\
Phd & Master degree & 30 & 5 \\
All managers & & 65 & 100 \\
\hline
\end{tabular}

\section{Reliability Analysis}

The Cronbach's alpha of all variables range from 0.623 to 0.731 . The smallest Cronbach's alpha (0.623) has been in dependent variable of employee organizational commitment and the highest Cronbach's alpha (0.731) has been in independent variable of organizational culture. The Cronbach's alpha for all variables 
(dependent and independent) have been above 0.6. According to Nunnally (1967), alpha coefficients are the minimum of 0.6 and above are considerably acceptable. (Table 2 )

\section{Descriptive Statistics}

The mean score of variables range from 2.111 to 3.17. The mean score of training and education and teamwork $(\mathrm{M}=3.13, \mathrm{M}=3.07)$ are moderate practices these organizations respectively. Organizational culture $(\mathrm{M}=3.092)$ which is moderate practices of their organization. The mean score of employees' organizational commitment (3.17) are moderate. The mean score of TQM practices $(\mathrm{M}=2.111)$ is low. The standard deviations range from 0.661 to 0.989 . The standard deviations for independent variables are quite high, indicating that the dispersion are widely spread distribution according to a normal distribution. (Table II).

\section{Correlation Analysis}

Correlation analysis is presented in table 2 .

Table 2

Mean, Standard Deviations, Reliability and Correlations for TQM Practices and Employees' Organizational Commitment $(N=100)$

\begin{tabular}{lcccccccc}
\hline & Mean & SD & Reliability & TE & T & OC & EOC & TQM \\
\hline Training and Education & 3.13 & 0.954 & 0.707 & 1 & & & & \\
$\begin{array}{l}\text { (TE) } \\
\text { Teamwork (T) }\end{array}$ & 3.07 & 0.989 & 0.712 & $.974^{* *}$ & 1 & & \\
$\begin{array}{l}\text { Organizational Culture } \\
\text { (OC) }\end{array}$ & 3.092 & 0.985 & 0.731 & $.987^{* *}$ & $.985^{* *}$ & 1 & \\
$\begin{array}{l}\text { Employee Organizational } \\
\text { Commitment (EOC) }\end{array}$ & 3.17 & 0.761 & 0.623 & $.928^{* *}$ & $.914^{* *}$ & $.925^{* *}$ & 1 \\
$\begin{array}{l}\text { Total Quality } \\
\text { Management (TQM) }\end{array}$ & 2.111 & 0.661 & & $.993^{* *}$ & $.993^{* *}$ & $.997^{* *}$ & $.928^{* *}$ & 1 \\
\hline
\end{tabular}

The correlations coefficients of all variables range from 0.914 to 0.997 . Training and education are strong correlations with employees' organizational commitment $(r=0.928)$. There are positively high correlations among teamwork with employees' organizational commitment $(\mathrm{r}=0.914)$. There is positively strong correlation among organizational culture with employees' organizational commitment $(r=0.925)$. There are positively high correlations among TQM practices with employees' organizational commitment $(\mathrm{r}=0.928)$.

\section{Simple Regression Analysis (SRA)}

SRA is used to explain the impact of change in TQM practices on employees' organizational commitment. SRA is also used to estimate the mathematical relationship between employees' organizational commitment and TQM practices shown in table 3.

Table 3

Test of Hypotheses Results

\begin{tabular}{|c|c|c|c|c|c|c|c|}
\hline S.No & Hypotheses & $\mathrm{R}^{2}$ & $\mathrm{~F}$ & Coeffi & cients & P-value & Results \\
\hline 1 & $\begin{array}{l}\text { H1: TQM particles have a positive } \\
\text { effect on employees' organizational } \\
\text { commitment. }\end{array}$ & 0.861 & 606.576 & 6.422 & 0.339 & 0.000 & Accepted \\
\hline
\end{tabular}


Silver Jubilee Issue - 2019

Training and education have a positive

2 effect on employees' organizational 0.861 607.929 5.986 1.035 commitment.

Teamwork has a positive effect

3 on employees' organizational

0.836 499.442

7.083

0.984

0.000

Accepted commitment. Organizational culture has a positive effect on employees' organizational 0.856 580.613 6.727 1.000 0.000

Accepted commitment.

$R^{2}$ is 0.861 , which means TQM practices explains around 86 percent of total variation in employees' organizational commitment. An overall model $(\hat{Y}=6.422+0.399 X)$ is fitted (P-value of $\mathrm{F}=0.000)$. Coefficient of organizational culture $(0.339)$ is positively significant $(\mathrm{P}$-value $=0.000)$. Coefficient of constant $(6.422)$ is also positively significant $(\mathrm{P}$-value $=0.000)$. Consequently, TQM practices have a positive effect on employees' organizational commitment is verified. Around 86 percent of total variation in employees' organizational commitment is explained by training and education $\left(R^{2}=0.861\right)$. An overall model is $(\hat{Y}=5.989+1.035 X)$ signified $(\mathrm{P}$-value of $\mathrm{F}=0.000)$. Coefficient of training and education $(1.035)$ is positively significant $(\mathrm{P}$-value $=0.000)$. Coefficient of constant $(5.989)$ is also positively significant $(\mathrm{P}$-value $=0.000)$. As a result, training and education have a positive effect on employees' organizational commitment is signified.

Teamwork explains around 84 percent of total variation in employees' organizational commitment $\left(R^{2}=0.836\right)$. An overall model $(\hat{Y}=7.083+0.984 X)$ is fitted (P-value of $\left.\mathrm{F}=0.000\right)$. Coefficient of teamwork $(0.984)$ is positively significant $(\mathrm{P}$-value $=0.000)$. Coefficient of constant (7.083) is also positively significant $(\mathrm{P}$-value $=0.000)$. Hence, teamwork has a positive effect on employees' organizational commitment is proved.

$R^{2}$ is 0.856 , which means organizational culture explains around 86 percent of total variation in employees' organizational commitment. An overall model $(\hat{Y}=6.727+1.000 X)$ is fitted (P-value of $\mathrm{F}=$ $0.000)$. Coefficient of organizational culture $(1.000)$ is positively significant (P-value $=0.000)$. Coefficient of constant $(6.727)$ is also positively significant $(\mathrm{P}$-value $=0.000)$. That's why, organizational culture has a positive effect on employees' organizational commitment is verified.

\section{Discussions}

The result of this paper reveals that TQM practices have a positive effect on employees' organizational commitment within ten Nepalese manufacturing industries. Successfully, TQM practices changes employees' organizational commitment. The result of this study is consistent with previous research which found that TQM practices had a significantly improvement on employees' organizational commitment (Guimaraes, 1996). This finding of the study is supported previous finding by Karia and Asaari, (2006) and Batista et al. (2013) found that TQM practices had positively significant impact on employees' organizational commitment. This paper's result is that training and education have a positive effect on employees' organizational commitment. Employees' organizational commitment is enhanced through training and education. This result is consistent with previous research which found that training and education was significantly positive related to organizational commitment (Ooi et al., 2005; KariaandAsaari, 2006). But, this result is inconsistent with the finding of Batista et al. (2013) regarding training and education did not demonstrate any favorable contribution to the organizational commitment. The result of this paper is that teamwork has a positive effect on employees' organizational commitment. Employees' organizational commitment is improved by teamwork. The current study is consistent with previous research, which found that teamwork was significantly positive related to employees' organizational commitment (Ooi et al., 
2005; KariaandAsaari, 2006). The present result is supported by Batista et al. (2013) found that teamwork had a significant and positive correlation with organizational commitment. The finding of this paper is that organizational culture has a positive effect on employees' organizational commitment. Employees' organizational commitment is enhanced through organizational culture. This finding is supported the previous finding by Ooi et al. (2005) which found that organizational culture was significantly positive related to employees' organizational commitment.

\section{Conclusion}

The objective of this paper is that TQM practices impact on employees' organizational commitment. TQM practices encourage employees' participation, promote empowerment, recognize that employees play an important role in achieving the organizations' objectives, and treat employees are primary resources. The present paper confirms that TQM practices enhance the employees' organizational commitment. The objective of this paper is that training and education impact on employees' organizational commitment. Training and education are essential for continuous improvement in employees' skills. Training and education explore the knowledge to employees. A successful training and education program create more favorable employee attitudes and loyalty, and help employees in their personal development and advancement. Hence, Training and education develop the employees' organizational commitment. This paper's objective is that teamwork impacts on employees' organizational commitment. Teamwork provides an atmosphere of mutual relationship, involvement and the participation throughout the organization. Teamwork is a work arrangement that arguably has the capacity to enable cooperation and effective individual involvement. Thus, teamwork improves the employees' organizational commitment. The objective of this paper is that organizational culture impacts on employees' organizational commitment. Organizational culture is considered to be a set of values shared among the employees. Organizational culture provides employees' capabilities and abilities to have control their work, to make changes to the organization. So, organizational culture changes on employees' organizational commitment.

\section{Implications}

This study provides some insights for managerial level employees for managing human resources in the manufacturing sector of Nepal. This study allows the industries to understand the different dimensions of TQM practices like training and education, teamwork, and organizational culture. It presents the relationship between TQM practices and employees' organizational commitment in Nepalese manufacturing industry. The research results in consistent with previous findings. There are many studies that claim the role of TQM practices in improving the overall employees' organizational commitment of the industry.

The managers in the Nepalese manufacturing sectors should pay attention to the importance of the different dimensions of TQM practices so that different types of TQM practices can be formulated and implemented in their manufacturing sectors. The results suggest that all TQM practices should be considered while formulating TQM polices. But, more emphasis is to be given to customer focus, training and education, teamwork, and organizational culture. The Nepalese manufacturing sector should emphasize more on achieving sustained competitive advantages in this competitive world.

Successfully, implementation of the TQM practices is used in the manufacturing industry to achieve organizational goals and to retain skillful and knowledgeable employee till long period. Further, automatically enhance employees' organizational commitment. The findings of this research are expected to provide references to managers of Nepalese manufacturing industries. Managers can design effective TQM practices for employees' organizational commitment.

Regarding practical implications, the top management should conduct formal TQM programs in the organization for all new employees and provide their existing employees with continuous formal training and education program (on- the- job as well as off- the- job) in order to gain employees' organizational commitment and subsequently reduce their turnover rate. This study also contributes by presenting very 
useful implications and recommendations for Nepalese manufacturing industries to properly implement TQM practices and improve their employees' organizational commitment.

It is proposed that future research should be conducted in other types of manufacturing industries using a similar approach. It is also important that other major constructs related to the TQM practices should be added to the conceptual framework underlying this study.

\section{References}

Agarwal, S., and Ramaswami, S. N. (1993). Affective organizational commitment of salespeople: An expanded model. Journal of Personal Selling and Sales Management, 13(2), 49-70.

Allen, N. J., and Meyer, J. P. (1996). Affective, continuance, and normative commitment to the organization: An examination of construct validity. Journal of Vocational Behavior, 49(3), 252-276.

Batista, M., Feijo, A., and Silva, F. (2013). Quality management and employees' attitudes: An example from certified enterprises. Management Research: The Journal of the IberoamericanAcademy of Management, 11(3), 260-279.

Boynton, A. C., and Zmud, R. W. (1984). An assessment of critical success factors. Sloan Management Review, 25(4), 17-27.

Dawson, P. (1994). Total Quality Management in J Storey (Ed) New Wave Manufacturing Strategies. London: Paul Chapman.

Flynn, B. B., Schroeder, R. G., andSakakibara, S. (1994). A framework for quality management research and an associated measurement instrument. Journal of Operations Management, 11(4), 339-366.

Gallear, D., and Ghobadian, A. (2004).An empirical investigation of the channels that facilitate a total quality culture. Total Quality Management and Business Excellence, 15(8), 1043-1067.

Grant, R. M., Shani, R., and Krishnan, R. (1994). TQM's challenge to management theory and practice. Sloan Management Review, 35(2), 25-35.

Guimaraes, T. (1996). TQM's impact on employee attitudes. The TQM Magazine, 8(1), 20-25.

Hill, S. (1991). Why quality circles failed but total quality management might succeed. British Journal of Industrial Relations, 29(4), 541-568.

Hoogervorst, J. A. P., Koopman, P. L., and Van der Flier, H. (2005). Total quality management: The need for an employee-centered, coherent approach. The TQM Magazine, 17(1), 92-106.

Hunt, V. D. (1992). Quality in America: How to Implement a Competitive Quality Program. Irwin professional publishing.

Karia, N., and Asaari, A. H. (2006). The effects of total quality management practices on employees' workrelated attitudes. The TQM Magazine, 18(1), 30-43.

Lau, H. C., and Idris, M. A. (2001). The soft foundation of the critical success factors on TQM implementation in Malaysia. The TQM Magazine, 13(1), 51-62.

Luthans, F. (1995). Organizational Behavior. $7^{\text {th }}$ ed. New York: McGraw-Hill.

Morgan, G. (1986). Images of Organizations. Beverly Hill: Sage Publication.

Mowday, R. T., Steers, R. M., and Porter, L. W. (1979). The measurement of organizational commitment. Journal of Vocational Behavior, 14(2), 224-247.

Nunnally, J. C. (1978). Psychometric Theory. $2^{\text {nd }}$ ed. New York, NY: McGraw-Hill.

Ooi, K. B., Arumugam, V., andHwa, T. S. (2005). Does soft TQM predict employees' attitudes?. The TQM Magazine, 17(3), 279-289.

Parker, S., and Wall, T. D. (1998). Job and Work Design: Organizing Work to Promote Well-Being and Effectiveness. London: Sage Publication.

Philips, Q. (1995). Philips Quality-Let's Make Things Better. Corporate Quality Bureau, Philips Electronics NV, Eindhoven.

Robbins, S. P., Judge, T.A.,and Sanghi, S. (2010). Essentials of Organizational Behavior. $10^{\text {thed. India: }}$ Pearson education. 
Ross, J. (1993). Total Quality Management: Text, Cases, and Readings. Delary Beach: St Lucie Press.

Rowntree, D. (1987). Statistics without Tears. New York, NY: Penguin Book.

Talib, F., and Rahman, Z. (2010). Critical success factors of TQM in service organizations: A proposed model. Services Marketing Quarterly, 31(3), 363-380.

Thapa, N. (2015). Total quality management and organizational performance in Nepalese tourism industry: the role of market orientation. Unpublished M. Phil thesis, Faculty of Management M. Phil Programme, Kathmandu.

Thapa, T. B. (2067). Educational Management and Organization Behavior. 2nd ed. Kathmandu: sunlight publication.

Thapa, T.B. (2011). Total Quality Management in Education. Academic Voices A Multidisciplinary Journal, l(1), 80-83.

Zhang, Z. (1999). Developing an Instrument for Measuring TQM Implementation in a Chinese Context. Groningen: University of Groningen. 
